\title{
Chromosome Stability and Inter-population Genetic Variability in a Tree Mangrove Xylocarpus granatum Koen. (Meliaceae) as Revealed by RAPD Markers
}

\author{
Anath Bandhu Das ${ }^{1, *}$ and Satya Narayan Jena ${ }^{2}$ \\ ${ }^{1}$ Cytogenetics Laboratory, Regional Plant Resource Centre, Nayapalli, Bhubaneswar 751015, \\ Orissa, India \\ ${ }^{2}$ Present address: Conservation and Molecular Taxonomy Laboratory, National Botanical \\ Research Institute, Lucknow-226001, Uttar Pradesh, India
}

Received September 12, 2007; accepted March 31, 2008

\begin{abstract}
Summary Detailed chromosome analysis of 8 populations of Xylocarpus granatum showed a constant somatic chromosome numbers of $2 n=48$ with a very symmetric karyotype. Structural details recorded no such major variation in the chromosome morphology. Random amplified polymorphic (RAPD) markers were used for determining the genetic diversity among 8 populations of this minor tree mangrove species. Individuals collected from several sites in north-east coast of India were analyzed for their genetic relationship. A total 444 amplicons were generated among the ecotypes out of which $\sim 67 \%$ bands were found polymorphic. Inter population polymorphism among 8 populations of $X$. granatum varied between 36.25 to $72.5 \%$. Clustering based on similarity index was done following Unweighted Pair Group with Arithmetic mean (UPGMA) method and intra-genetic relationships were analysed. The obtained dendrogram of the RAPD data showed prominent patterns of interpopulation relationships that are discussed in the light of the respective habitats of the ecotypes distributed in different mangrove pockets of the north-east Indian sea coast. It was evident from RAPD data that high degree of divergence exists among 8 studied populations, which suggests their adaptation in various microclymatic condition is suitable for the specific habitat of a particular ecotype.
\end{abstract}

Key words Karyotype, Mangrove, RAPD markers, Somatic chromosome, Xylocarpous.

The widespread loss of the world's biological diversity is one of the most serious global crises today. Conservation of the endangered plant species is the most effective means of preventing the crisis. When an endangered species is vegetatively propagated which is located in a state of collection of few genotypes, collection of individuals for conservation purpose becomes critical. Because of the long-term life cycle, tree genetics tends to receive less attention than annual crops. Among tree species, mangrove plants have not so far been subjected to detailed genetic analysis (Balakrishna 1995). Mangrove forests form the interface between marine and terrestrial environments and stretch from the inter-tidal zone up to the high-tide mark. These forests are comprised of twelve genera comprising about 60 species of salt-tolerant trees. Out of several cosmopolitan species of mangrove, Xylocarpus granatum of the family Meliaceae is an important species because it withstand varying soil conditions, high level of salinity, and lack of freshwater inflow for considerable periods of time and pollution of varying forms (Scholander et al. 1955). Because of their intertidal location, Xylocarpus granatum have developed a number of morphological and physiological adaptations to cope with the salt water from the ocean and live within specific zones in their ecosystem. Genetic characterization of mangroves is unfortunately limited owing to lack of concerted studies on identifying the genetic variability within species. This species produces gigantic seeds only of 2

*Corresponding author, e-mail: a_b_das@hotmail.com 
to 3 with in a fruit due to cross pollination and fruits are not produced so profuse; regeneration is limited with a hurdle of various biotic and abiotic factors. Since all the regenerations are of seed origin it is therefore essential to find out its genetic variability for better understanding of ecological management of this threatens species in various climatic conditions. There is no report on the chromosome number as well as a DNA marker study in analyzing genetic diversity of Xylocarpous except for very few species of mangroves like Acanthus, (Lakshmi et al. 1997, Jena et al. 2002), Avicennia (Parani et al. 1997), and Heritiera (Das et al. 2001). For evaluation of genetic diversity in species where cloned markers are not available, RAPDs are better choice of markers. Hence, RAPD analysis was undertaken in Xylocarpus granatum that showed clear inter-population variability from the collections made in Orissa and West Bengal of India being a home of complex and varied vegetation structure for conducive growth of diverse floral elements. This present study describes the result of a molecular-marker-based analysis (RAPD) of a minor mangrove, Xylocarpus granatum along with the cytological analysis, which is present as distinct 8 populations along the coastline of North East India; edged by the distance which is a common measure used to indicate the intensity of habitat fragmentation.

\section{Materials and methods}

\section{Plant materials}

Xylocarpus granatum Koen populations were collected from eight different sites from North-East Indian sea coast; the name of populations, their source of collection, salinity range, soil type and location details have been depicted in Table 1. An equal quantities of young leaf sample from single plant of each populations were collected separately which is demarked as Accessions and stored in $\mathrm{a}-85^{\circ} \mathrm{C}$ freezer for DNA extraction.

\section{Cytological studies}

Young and healthy root-tips were pretreated in saturated paradichloro-benzene and aesculine mixture for $4 \mathrm{~h}$ at $18^{\circ} \mathrm{C}$ followed by overnight fixation in propionic acid: ethanol $(1: 3)$. Chromosome staining was done in $2 \%$ propionic orcein after cold hydrolysis in $5 \mathrm{~N} \mathrm{HCl}$ for 7 min. Root-tips were squashed in $45 \%$ propionic acid. Well-scattered 10 metaphase plates were selected for karyotype analysis of each species. The total chromosome length was ascertained by adding the length of all 
Table 2. Detailed karyotype of $X$. granatum Pop-VI collected from Sundarbans showing somatic chromosome characteristics

\begin{tabular}{cccccl}
\hline \hline $\begin{array}{c}\text { Types of } \\
\text { chromo- } \\
\text { some }\end{array}$ & $\begin{array}{c}\text { Number of } \\
\text { chromo- } \\
\text { somes }\end{array}$ & $\begin{array}{c}\text { Total length } \\
\text { of chromo- } \\
\text { somes }(\mu \mathrm{m})\end{array}$ & $\begin{array}{c}\text { Total length } \\
\text { of short } \\
\text { arm }(\mu \mathrm{m})\end{array}$ & $\begin{array}{c}\text { Form } \% \\
(\mathrm{~F} \%)\end{array}$ & Chromosome characteristics \\
\hline A & 2 & 4.64 & 1.00 & 46.40 & Two constrictions one in median and the other \\
& 14 & 16.96 & 7.80 & 45.99 & in the nearly sub-terminal in position. \\
C & 18 & 9.84 & 4.03 & 40.95 & Nearly medium primary constriction. \\
C & 8 & 23.36 & 6.34 & 27.14 & Nearly sub-terminal primary constriction. \\
D & 8 & & & & \\
\hline
\end{tabular}

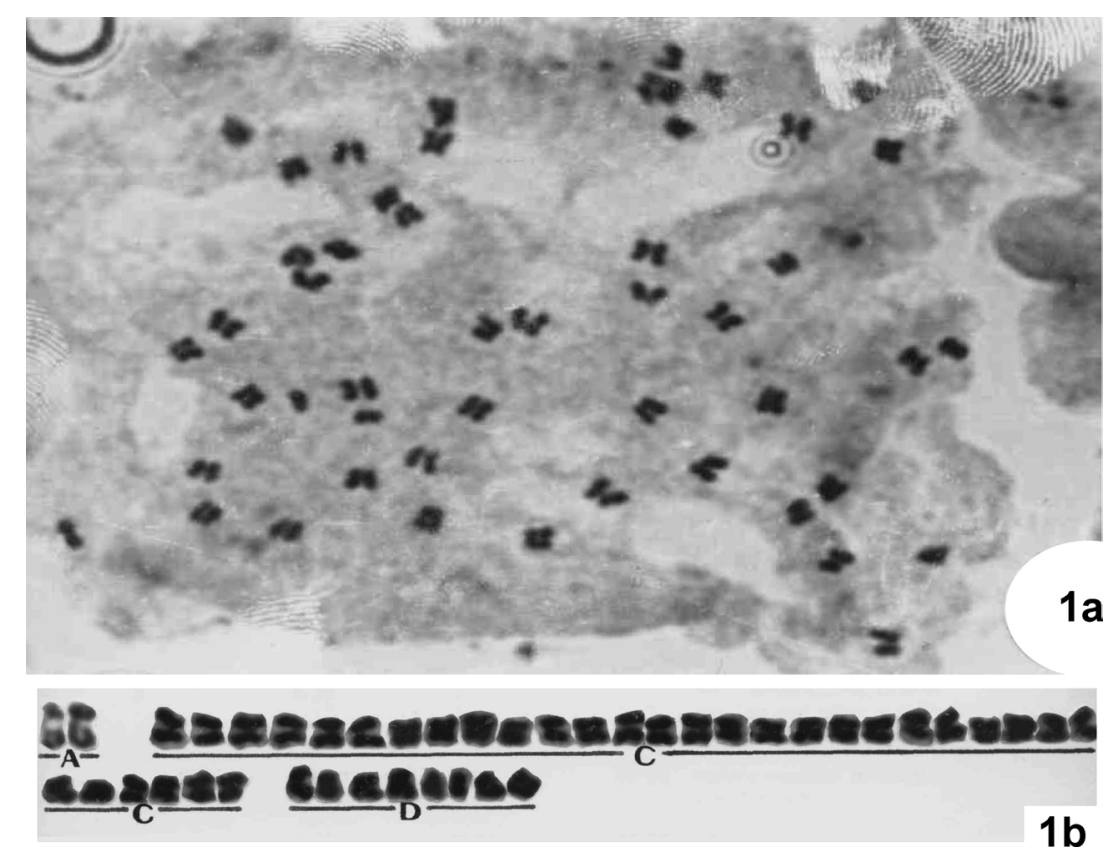

Fig. 1. (a) Somatic metaphase chromosome $2 n=48$ and (b) idiogram of Xylocaprous granatum Pop. Bhitarkanika.

chromosomes in the karyotype and the total chromosome volume of a karyotype was calculated by applying the formula $\pi \mathrm{r}^{2} \mathrm{~h}$, where ' $\mathrm{r}$ ' and ' $\mathrm{h}$ ' represent the radius and length of the chromosome, respectively. The form \% (F\%) of each chromosome was calculated following the method of Levan et al. (1964). Total form percentage of karyotype was the average of $\mathrm{F} \%$ of a karyotype. Mean values of total genomic chromosome length and total chromosome volume with standard error were calculated.

\section{Isolation of DNA}

For DNA isolation, $5 \mathrm{~g}$ of leaf tissue were ground to fine power with liquid nitrogen and the power was suspended in $30 \mathrm{ml}$ of suspension buffer ( $\mathrm{pH}$ 8.0) containing $50 \mathrm{mM}$ EDTA, $100 \mathrm{mM}$ Tris- $\mathrm{HCl}, 0.8 \mathrm{M} \mathrm{NaCl} .0 .5 \mathrm{M}$ sucrose, $2 \%$ Triton $\times 100$ and $0.1 \% \beta$-mercapto-ethanol and incubated at $60^{\circ} \mathrm{C}$ for $30 \mathrm{~min}$. The suspension was centrifuged at $10,000 \mathrm{~g}$ for $15 \mathrm{~min}$ at room temperature and the pellet was suspended in $20 \mathrm{ml}$ of extraction buffer $(20 \mathrm{mM}$ EDTA, $100 \mathrm{mM}$ Tris-HCl, $1.5 \mathrm{M}$ $\mathrm{NaCl}, 2 \% \mathrm{CTAB}$ and $1 \% \beta$-mercaptoethanol, $\mathrm{pH} 8.0$ ). Again the suspension was incubated at $60^{\circ} \mathrm{C}$ for $45 \mathrm{~min}$ followed by chloroform : isoamyle alcohol $(24: 1)$ extraction and ethanol precipitation at $-20^{\circ} \mathrm{C}$ for $2 \mathrm{~h}$. 
Table 3. RAPD primers, their nucleotide sequence \& number of RAPD bands generated from eight different populations of $X$. granatum

\begin{tabular}{|c|c|c|c|c|c|c|c|c|c|c|}
\hline \multirow{2}{*}{ Primer } & \multirow{2}{*}{$\begin{array}{l}\text { Primer Sequence } \\
\qquad\left(5^{\prime}-3^{\prime}\right)\end{array}$} & \multirow{2}{*}{$\begin{array}{l}\text { Total No. } \\
\text { of bands }\end{array}$} & Pop-I & Pop-II & Pop-III & Pop-IV & Pop-V & Pop-VI & Pop-VII & Pop-VII \\
\hline & & & $\mathrm{P}(\mathrm{U})$ & $\mathrm{P}(\mathrm{U})$ & $\mathrm{P}(\mathrm{U})$ & $\mathrm{P}(\mathrm{U})$ & $\mathrm{P}(\mathrm{U})$ & $\mathrm{P}(\mathrm{U})$ & $\mathrm{P}(\mathrm{U})$ & $\mathrm{P}(\mathrm{U})$ \\
\hline 1. OPA 8 & GTCACGTAGG & 58 & $7(1)$ & $6(0)$ & $6(0)$ & $7(0)$ & $7(0)$ & $2(5)$ & $3(0)$ & $5(1)$ \\
\hline 2. OPA11 & CAATCGCCGT & 45 & $5(1)$ & $5(0)$ & $5(0)$ & $4(1)$ & $4(0)$ & $4(2)$ & $3(0)$ & $3(0)$ \\
\hline 3. OPA14 & TCTGTGCTGG & 41 & $3(0)$ & $3(1)$ & $3(1)$ & $2(1)$ & $2(1)$ & $5(3)$ & $4(0)$ & $4(0)$ \\
\hline 4. OPD 8 & GTGTCCCCCA & 46 & $5(1)$ & $5(1)$ & $5(0)$ & $4(0)$ & $4(1)$ & $4(1)$ & $3(1)$ & $3(0)$ \\
\hline 5. OPN 4 & GACCGACCCA & 41 & $2(1)$ & $2(0)$ & $4(0)$ & $4(1)$ & $4(1)$ & $3(2)$ & $3(2)$ & $3(1)$ \\
\hline 6. OPD 2 & GGACCCAACC & 49 & $5(0)$ & $4(2)$ & $4(1)$ & $3(1)$ & $3(1)$ & $4(2)$ & $5(1)$ & $5(0)$ \\
\hline 7. OPD12 & CACCGTATCC & 51 & $4(0)$ & $5(0)$ & $5(0)$ & $6(0)$ & $6(0)$ & $2(4)$ & $4(0)$ & $7(0)$ \\
\hline 8. OPN11 & TCGCCGCAAA & 30 & $2(0)$ & $2(0)$ & $4(0)$ & $4(0)$ & $3(0)$ & $0(3)$ & $2(0)$ & $2(0)$ \\
\hline 9. OPN15 & CAGCGACTGT & 39 & $3(1)$ & $2(1)$ & $3(1)$ & $4(0)$ & $4(0)$ & $4(2)$ & $3(0)$ & $3(0)$ \\
\hline 10. OPA5 & AGGGGTCTTG & 44 & $4(0)$ & $4(1)$ & $3(2)$ & $3(1)$ & $4(0)$ & $5(1)$ & $3(1)$ & $3(1)$ \\
\hline \multicolumn{2}{|c|}{ Total 10 primers } & 444 & $40(5)$ & $38(6)$ & $42(5)$ & $41(5)$ & $41(4)$ & $33(25)$ & $33(5)$ & $38(3)$ \\
\hline
\end{tabular}

Pop-population, P- number of polymorphic band, U-number of unique band.

Table 4. Similarities index among the eight populations of $X$. granatum using RAPD markers

\begin{tabular}{lcccccccc}
\hline \hline & Pop I & Pop II & Pop III & Pop IV & Pop V & Pop VI & Pop VII & Pop VIII \\
\hline Pop I & 100 & & & & & & & \\
Pop II & 78.6 & 100 & & & & & & \\
Pop III & 78.6 & 67.6 & 100 & & & & & \\
Pop IV & 80.5 & 69.4 & 93.5 & 100 & & & \\
Pop V & 83.4 & 68.1 & 86.7 & 91.3 & 100 & & \\
Pop VI & 63.7 & 67.8 & 60.4 & 63.5 & 60.4 & 100 & & \\
Pop VII & 61.6 & 72.8 & 47.2 & 47.6 & 48.5 & 42.6 & 100 & \\
Pop VIII & 69.3 & 85.3 & 63.8 & 63.7 & 54.4 & 60.4 & 78.4 & 100 \\
\hline
\end{tabular}

DNA was hooked out and dried with vacuum drier and a very much less amount of TE $(10 \mathrm{mM}$ Tris-HCl, 1 mM EDTA) was added so as to dissolve the DNA. The DNA again purified treating with $\mathrm{RNase}$ at $37^{\circ} \mathrm{C}$ for $1 \mathrm{~h}$ followed by chloroform: isoamylalcohol extraction and ethanol precipitation in the presence of $0.3 \mathrm{M}$ sodium acetate $(\mathrm{pH}$ 5.2). The DNA was spooled out, washed in $70 \%$ ethanol, air dried and dissolved in TE buffer and the DNA concentration was estimated in Versafluor TM Fluorometer (Bio-Rad, USA) using Hoechst 33258 as the flurimetric dye. The DNA was diluted to final concentration of $25 \mathrm{ng} \mu \mathrm{l}^{-1}$ using TE buffer for using as template for RAPD analysis.

\section{RAPD analysis}

RAPD profiles were generated by using single decamer random oligonucleotide primers (Operon Technologies, Alameda, USA) in polymerase chain reaction (PCR) following the standard protocol of Williams et al. (1990). The sequence of primer is given in Table 2. Each polymerase chain reaction (PCR) amplification reaction mixture of $25 \mu$ l contained $25 \mathrm{ng}$ of genomic template DNA, $200 \mathrm{mM}$ of each dNTP, $25 \mathrm{ng}$ of primer, 0.5 unit of Taq DNA Polymerase (Bangalore Genei Pvt. Ltd., Bangalore, India) and $10 \times \mathrm{PCR}$ assay buffer $(50 \mathrm{mM} \mathrm{KCl}, 10 \mathrm{mM}$ Tris- $\mathrm{HCl}, 1.5 \mathrm{mM}$ $\mathrm{MgCl}_{2}, \mathrm{pH}$ 9.0). The PCR reaction of the cocktail was carried out in a GeneAmpPCR 2400 thermal cycler (Perkin Elmer, USA) programmed for 45 cycles. The first cycle was programmed for 5 min at $94^{\circ} \mathrm{C}$ for denaturation, $1 \mathrm{~min}$ at $40^{\circ} \mathrm{C}$ for primer annealing and $2 \mathrm{~min}$ at $72^{\circ} \mathrm{C}$ for DNA polymerization. In the next 44 cycles the period of denaturation was maintained at 1 min while the primer annealing and DNA polymerization was same as in the first cycle. An additional cycle of $15 \mathrm{~min}$ at 

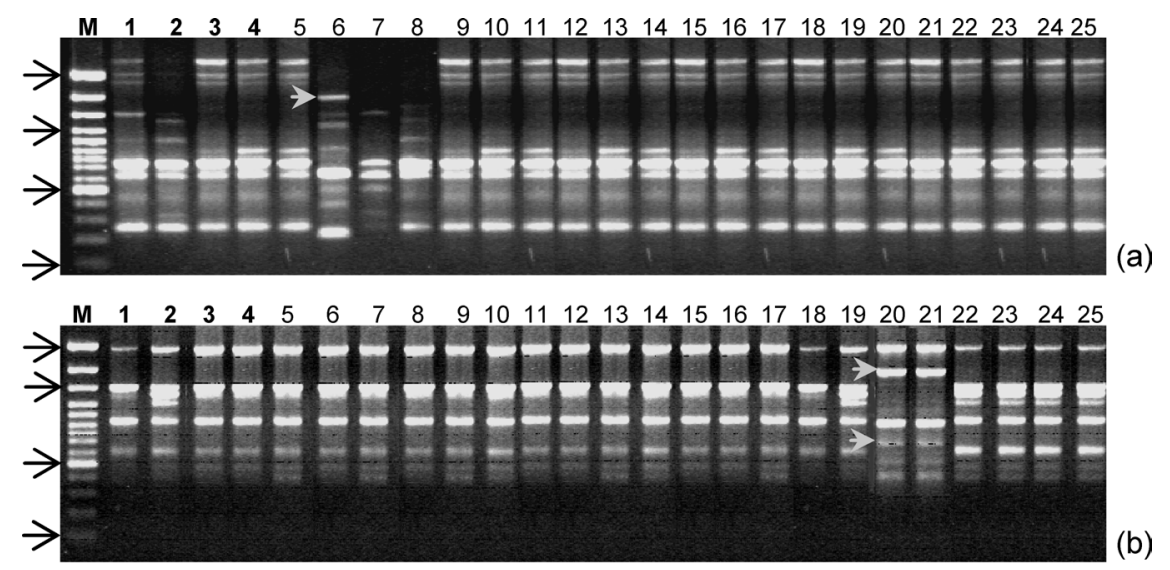

(b)

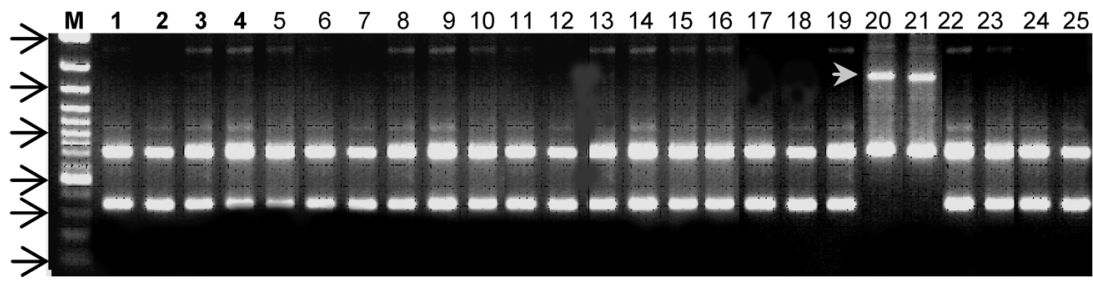

(c)

Fig. 2. Amplification profiles of 25 accessions of eight populations of $X$. granatum using OPA-08 (a), OPD-12 (b) and OPN-11 (c); DNA marker (M) Gene Ruler 100 bp DNA kadder plus (MBI Fermeantas, Lithuania). Pop-I $=1,2,3$ accessions, PoP-II =4, 5, 6, 7 accessions, Pop-III =8, 9, 10, 11 accessions, Pop-IV=12, 13, 14, 15, 16 accessions, Pop-V=17, 18, 19 accessions, Pop-VI=20, 21 accessions, Pop-VII=22, 23 accessions, Pop-VIII=24, 25 accessions).

Table 5. Genetic distance among the eight populations in X. granatum using RAPD markers

\begin{tabular}{|c|c|c|c|c|c|c|c|}
\hline & Pop I & Pop II & Pop III & Pop IV & Pop V & Pop VI & Pop VII \\
\hline Pop II & 21.4 & & & & & & \\
\hline Pop III & 21.4 & 32.4 & & & & & \\
\hline Pop IV & 19.5 & 30.6 & 6.5 & & & & \\
\hline Pop V & 16.6 & 31.9 & 13.3 & 8.7 & & & \\
\hline Pop VI & 36.3 & 32.2 & 39.6 & 36.5 & 39.6 & & \\
\hline Pop VII & 38.4 & 27.2 & 52.8 & 52.4 & 51.5 & 57.4 & \\
\hline Pop VIII & 30.7 & 14.7 & 36.2 & 36.3 & 45.6 & 39.6 & 21.6 \\
\hline
\end{tabular}

$72^{\circ} \mathrm{C}$ was used for primer extension. The amplified samples were stored at $4{ }^{\circ} \mathrm{C}$ and separated by electrophoresis in 1.5 agarose gel in $1 \times$ TAE buffer for $3 \mathrm{~h}$ at $50 \mathrm{~V}$. To determine the size of the polymorphic fragments. Gene Ruler $100 \mathrm{bp}$ DNA ladder plus (MBI Fermantas, Lithuania) was used as size standard. DNA fragments were visualized by staining the gel with ethidium bromide and photographed for documentation.

\section{RAPD data scoring and analysis}

In RAPD analysis, the presence or absence of the bands were taken into consideration and the difference in the intensity of the band was ignored. From RAPD data a binary matrix was obtained. The matrix elaborated utilizing the multivariate analysis program NTSYS-pc (Rohlf 1993). The binary matrix was transformed in a similarity matrix using the Jacquard's similarity coefficient. The cluster analysis was carried out using the UPGMA (Unweighted pair group mean average) method (Sokal and Rohlf 1973). 


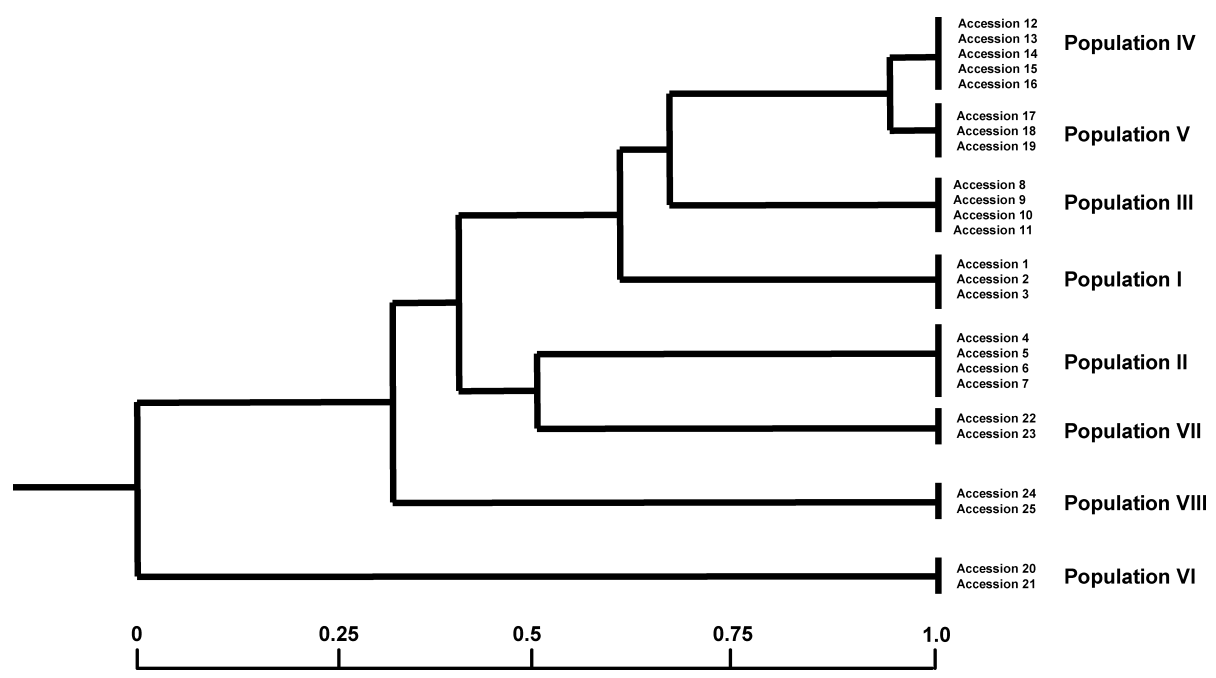

Fig. 3. UPGMA dendrogram of eight population of Xylocarpus granatum obtained on the RAPD markers.

Results

\section{Chromosome characteristics}

Somatic chromosomes $2 n=42$ was observed in all the populations of Xylocarpous granatum. The karyotype was symmetric in all the ecotypes with major variations of chromosome morphology. Chromosome length varied from $2.28 \mu \mathrm{m}$ to $3.25 \mu \mathrm{m}$; total chromosome length $54.80 \mu \mathrm{m}$ and total chromosome volume of $56.23 \mu \mathrm{m}^{3}$. The following types of chromosomes were found in the different populations of $X$. granatum;

Type A-Chromosomes are medium to small in size with two constrictions, one in nearly median and the other in nearly sub-terminal position.

Type $\mathrm{C}-$ Chromosomes are of small in size and having nearly sub-median constrictions.

Type D-Chromosomes are of small in size and having nearly sub-terminal chromosomes.

The detailed karyotypic analysis of a single population is presented in Table 2 (Fig. 1a) for understanding of the type of chromosomes (for other populations data not shown). In general variation of Type C and Type D chromosomes were observed among the populations. Since, the chromosome are very small in size not much of significant variations could be established to distinct the populations genetically.

\section{RAPD analysis}

Eight populations of $X$. granatum collected from eight different places showed some amount of DNA markers variations in population level. The number of amplification products ranged from 37 to 76 for eight different populations (Table 3) and polymorphism was between $36.25 \%$ to $72.5 \%$. A total of 444 amplification products were observed of which was polymorphic (67.22\%). RAPD profiles of eight different regions shared a number of common bands for all primers. The average number of amplification product obtained with one primer was $11.9 \%$ and $9.52 \%$ of the products were polymorphic. Population-VI showed a highest number polymorphic bands (58 bands out of 80 bands) generated by various primers showing a polymorphism of $72.5 \%$ (Tables 3 and 4 , Figs. $2 a, b$, c). The profiles were very distinct out of the studied eight genotypes of different populations. RAPD profiles of eight populations with their representative accessions were amplified by different primers out of which OPA-8, OPD-12, and OPN-11 showed distinct DNA profile of each population without any significant variation between/among the plants collected under each populations (Figs. 2a, b, c).

In OPA-8, two high DNA markers of $3750 \mathrm{bp}$ and $2630 \mathrm{bp}$ were found to be unique to Pop-I, 
Pop-III, Pop-IV and Pop-V in contrast to $3000 \mathrm{bp}$ was not found in last two regions. The unique DNA bands of $2010 \mathrm{bp}, 1270 \mathrm{bp}, 925 \mathrm{bp}, 380 \mathrm{bp}$ and $230 \mathrm{bp}$ were only obtained in Pop-VI-region while $1000 \mathrm{bp}$ and $340 \mathrm{bp}$ DNA fragments were confirmed to Pop-IV, Pop-V (Fig. 2a). DNA marker with $740 \mathrm{bp}$ and $460 \mathrm{bp}$ were reported in all populations except Pop-VI population while $506 \mathrm{bp}$ was confirmed to population Pop-VI and Pop-VII. DNA band with 3300 bp, 2140 bp 1030 bp and 770 bp were unique to Pop-VI in OPD-12 primer. In that same primer DNA bands of $2900 \mathrm{bp}, 1500 \mathrm{bp}$ and $930 \mathrm{bp}$ were found in all population besides Pop-VI. The DNA band with $1200 \mathrm{bp}$ was found to be marker in Pop-II, Pop-VI and Pop-VIII whereas DNA band of 625 bp was a monomorphic band. DNA fragment, having 2530 bp was a good marker that was not found only in Pop-V, Pop-VI, PopVII with primer OPN-11 while $970 \mathrm{bp}, 725 \mathrm{bp}$ and $350 \mathrm{bp}$ DNA fragment were found in all populations except Pop-VI. In Pop-VI, there were a number of unique bands of $2190 \mathrm{bp}, 1770 \mathrm{bp}$ and $490 \mathrm{bp}$ (Fig. 2b). In OPN-4 primer, $1300 \mathrm{bp}$ and $1064 \mathrm{bp}$ DNA bands were found to be marker to Pop-III and Pop-V whereas 2200 bp DNA fragment was found to only Pop-IV and Pop-VII (Fig. 2c).

\section{Cluster analysis}

Pair wise comparisons were made for the RAPD profiles obtained from RAPD markers of eight populations of $X$. granatum showed a single tree with Pop-VI as a out group and rest are in a single cluster (Table 5, Fig. 3). Furthermore, that cluster again showed a out group of Pop-VIII, where the rest populations showed the cluster divided into two sub cluster confirm two distinct branch of the tree. Pop-VII and Pop-II showed closer affinity whereas pop-I, Pop-III showed relatively distinct relationships ratherthan the very close affinity of pop-IV and Pop-V through the use of 10 random primers in the representative samples of all eight populations.

\section{Discussion}

Chromosome number of all the 8 populations of $X$. granatum showed $2 n=42$ chromosomes. Since the chromosomes were found very small, it was very difficult to find out any visual differences in the population level. As a result the RAPD marker analysis was made on all the populations and we could find some important observations and population specific bands that could distinguished Pop-VI as a genetically separate group of plants under the species $X$. granatum. The average number of amplification product obtained with one primer was $11.9 \%$ and $9.52 \%$ of the products were polymorphic. Pop-VI collected from Sundarbans of West Bengal showed a highest number of polymorphic bands (58 bands out of 80 bands) with $72.5 \%$ of polymorphism (Figs. 2a, b, c). The profiles were very distinct out of the studied eight genotypes of different populations. RAPD profiles of eight populations with their representative accessions were amplified by different primers out of which OPA-8, OPD-12, and OPN-11 showed distinct DNA profile of each population without any significant variation between/among the plants collected under each populations (Figs. 2a, b, c). This type of genetic variation in ecotype level was found in other mangrove associate like Acanthus ilicifolius (Jena and Das 2004).

The unique DNA bands of $2010 \mathrm{bp}, 1270 \mathrm{bp}, 925 \mathrm{bp}, 380 \mathrm{bp}$ and $230 \mathrm{bp}$ were only obtained in Pop-VI-region while $1000 \mathrm{bp}$ and 340 bp DNA fragments were the characteristics of Pop-IV, Pop-V (Fig. 2a). Distinct common DNA markers of $740 \mathrm{bp}$ and $460 \mathrm{bp}$ were reported in all populations except Pop-VI while 506 bp was confirmed to population Pop-VI and Pop-VII. DNA band with 3300 bp, 2140 bp 1030 bp and 770 bp were unique to Pop-VI in OPD-12 primer. In that same primer DNA bands of $2900 \mathrm{bp}, 1500 \mathrm{bp}$ and $930 \mathrm{bp}$ were found in all population besides Pop-VI. In Pop-VI, there were a number of unique bands of $2190 \mathrm{bp}, 1770 \mathrm{bp}$ and $490 \mathrm{bp}$ (Fig. 2b). In OPN-4 primer, $1300 \mathrm{bp}$ and $1064 \mathrm{bp}$ DNA bands were found to be marker to Pop-III and Pop-V whereas $2200 \mathrm{bp}$ DNA fragment was found to only Pop-IV and Pop-VII (Fig. 2c).

Phylogenetic analysis of all the 8 populations showed a single tree with Pop-VI as a out group 
and rest are in a single cluster. That confirms the significant genetic variability in Pop-VI. Pop-VII and Pop-II showed closer affinity whereas Pop-I, Pop-III showed relatively distinct relationships.

Mangroves exist in a constantly changing environment. Periodically the sea inundates the community with salty water while, at low tide, especially during periods of high rainfall, it may be exposed to floods of fresh water. Apart from suddenly altering the salinity levels, these fluctuations in water can alter temperatures as well. Mangroves are constantly subjected to physiological stress caused by fluctuating growing conditions (Chapeker 1994). Despite such extremes, they have successfully colonized suitable areas by developing morphological, physiological and reproductive adaptations (Clough et al. 1982, Clough 1994, Saenger 1982). Therefore, depending on the genetic architecture of these species and their edaphic preferences and adaptations, different species are likely to display varying degrees of polymorphism. Present observations on $X$. granatum do support this presumption. This is because of its several and varied adaptational and distributional patterns. RAPD was analyzed on eight populations and the variability patterns were scored on the basis of amplified products. However the overall polymorphism in this species is of high magnitude. The observed inter-population divergence could be ascribed to the fluctuating microclimatic conditions in the regions where these genotypes inhabit. The analysis was carried out not only on a pair wise combination of variability but also accounted for the entire information given by all the genotypes against all the primers used.

The genetic resources of a species exist at two fundamental levels: i) genetic differences between individuals within a local population and ii) genetic differences between different local populations. Population genetics theory emphasized the evolutionary importance of the genetic structure of the species, that is, the distribution of genetic variation within and between populations. However, only in the last 15 years, through the eletrophoretically detection of genetic variation at many protein loci, has it been practical to describe the amounts and distribution of genetic variation in natural populations (Nei 1975). Population structure is studied to answer a broad range of questions that can be study of ecotypic differentiation by investigating the influence of natural selection on population structure. Significant genetic differentiation is aimed to find between populations and specific fragments may be associated with soil types (Nevo et al. 1994, Dawson et al. 1993). Efforts to pressure genetic resources must take in to account the components of genetic variation, both within and between local populations.

The distribution of genotypes observed on the dendrogram is represented in Fig. 3. and shows that the RAPD data can be a powerful tool in assessing the genetic diversity. With regard to intra-site variability, genetic diversity within $X$. granatum collected from the same sites is very low. This is surprising because the species have evolved from the same habitats for a long period of time. The frequent inundation of seawater might have helped cross-pollination to account for this polymorphism. Though the dendrogram is quite revealing the groups are considered different with respect to sites. Two major components of genetic diversity within species is basically exist. Adaptive divergence e.g. that along gradients of selection is expected to result in phenotypic difference among population and does not require completes suppression of gene flow. By constant isolation is expected to result in phylogeographic structure at neutral molecular markers but does not necessarily result in phenotypic difference where both process operate, the resulting phenotypically and phylogenetically distinct populations can be recognized as distinct taxonomic entities (Avise and Ball 1990). Both molecular and phenotypic measures of divergence should be considered while measuring the diversity (Dizon et al. 1992, Vogler and Desalle 1994, Waples 1995). The evolutionary potential of individual populations can be predicted from their genetic makeup. The isolation combined with genetic drift/divergence selection will generate unique and irreplaceable combinations of genotypes, which may or may not be manifest as differences in phenotypes. This process of isolation and divergence was well studied here using molecular markers. In this case there is the significant phylogeographic structure. It is concluded that genetic diversity due to geographically isolation is not potentially re- 
placeable. The genetic diversity within populations limits the response to selection especially in stressful or ecologically marginal environment.

\section{Aknowledgements}

We would like to acknowledge the Ministry of Environment, Government of India for supporting the financial assistance [Grant No. 3/7/2000-CS (M)] to carry out this work. We also acknowledge the help extended by Institute of Physics, Bhubaneswar, DST, Govt. of India providing liquid nitrogen free of cost.

\section{References}

Avise, J. C., and Ball, R. M. 1990. Principles of genealogical concordance in species concepts and biological taxonomy. In: Futuyama, D. and Antonovics, J. (eds) Oxford Surveys in Evolutionary Biology Vol. 7, pp. 45-67. Oxford University Press, New York.

Balakrishna, P. 1995. Evaluation of intra-specific variability in Avicennia marina Forsk using RAPD markers. Curr. Sci. 69: 926-929.

Chapeker, S. B. 1994. Population dynamics in mangroves. In: Conservation of mangrove generic resources: atraining manual. (Eds.) Deshmukh, S. V., Balagi, V., ITI' O-CRSARD project, MSSRF, Madras. India, pp. 159-164.

Clough, B. F., Andrew, P. J. and Cowan, I. R. 1982. Physiological processes. In: Clough BF (ed) Mangrove ecosystems in Australia: structure, function and management. Aust Natl Univ Press, Canberra, pp. 194-210.

— 1994. Climatic impacts on mangrove ecosystems. In: Deshmukh, S. V., Balaji, V. (eds) Conservation of mangrove genetic resources: a training manual. ITTO-CRSARD Project, MSSRF, Madras, India, pp. 39-43.

Das, A. B., Mukherjee, A. K. and Das P. 2001. Molecular phylogeny of Heriteria Aiton (Sterculiaceae), a tree mangrove: variations in RAPD markers and nuclear DNA content. Bot. J. Linn. Soc. 136: 221-229.

Dawson, I. K., Chalmers, K. J., Waugh, R. and Powell, W. 1993. Detection and analysis of genetic variation in Hordeum spontaneum population from Israel using RAPD markers. Mol. Eco. 3: 151-159.

Dizon, A. E., Lockyer, C., Perrin, W. F., DeMaster, D. P. and Sisson, J. 1992. Rethinking the stock concept: aphylogeogr aphic approach. Conser. Biol. 6: 24-36.

Jena, S., Sahoo, P., Mohanty, S., Das, A. B. and Das, P. 2002. Karyotype variation and cytophotometric estimation of in situ DNA content in some minor and associate mangroves of India. Cytologia 67; 15-24.

— and Das, A. B. 2004. Genetic variability in six ecotypes of a mangrove Acanthus ilicifolius L. as revealed by genome size and RAPD markers. Cytologia 69: 131-139.

Lakshmi, M., Rajalakshmi, S., Parani, M., Anuratha, C. S. and Parida, A. 1997. Molecular phylogeny of mangroves I: Use of molecular markers in assessing the genetic variability in the mangrove species Acanthus ilicifolius Linn. (Acanthaceae) Theor. Appl. Genet. 94: 1121-1127.

Levan, A., Fredya, K. and Sandberg, A. 1964. Nomenclature for centromeric position on chromosome. Heridity 52: $201-220$.

Nei, M. 1975. Molecular population genetics and evolution. American Elsevier, New York.

Nevo, E., Krugman, T. and Beiles, A. 1994. Edaphic natural selection of allozyme polymorphisms in aegilops peregrina at a Galilee microsite in Israel. Helidity 72: 109-112.

Parani, M., Lakshmi, M., Elango, S., Ram, N., Anuratha, C. S. and Parida, A. 1997. Molecular phylogeny of mangroves II Inter and intra specific variation in Avicennia revealed by RAPD and RFLP markers. Genome 40: 487-495.

Rohlf, F. J. 1993. Ntsys-PC. Numerical taxonomy and multivariate analysis system Version 1. 80-Setauket, NY, Exeter Software.

Saenger, P. 1982. Morphological, anatomical andreproductive adaptations of Australian mangroves. In: Ecosystems of the World (Eds.) Chapmann, V. J. Vol 1: Wet Coastal Ecosystems. Amsterdam: Elsevier pp. 231-238.

Scholander, P. F., van Dam, L., and Scholander, S. I.,1955. GAs exchange in the roots of mangroves. American Journal of Botany 42: 92-98.

Sokal, P. R. and Rohlf, J. 1973. Introduction to Biostatistics. Freeman, San Franscisco.

Vogler, A. P. and DeSalle, R. 1994. Diagnosing units of conservation management. Conservation Biology 8: 354-360.

Waples, R. S. 1995. Evolutionary significant units and the conservation of biologicaldiversity under the endangered species act. Pages 8-27 in Nielsen, J. L., Editor. Evolution and the aquatic ecosystem: defining unique units in population conservation. American Fisheries Society, Bethesda MD.

Willams, J. G. K., Kulelik, A. R., Liver, J., Rafalski, A. and Tingey, S. V. 1990. DNA polymorphism identification by arbitrary primers are useful as genetic markers. Nucleic Acids Res. 18: 6531-6535. 